\title{
COOPERATION IN A HYdRo-Geologic COMMONS: New Institutions and Pricing to AChieve Sustainability and SeCurity
}

\author{
Edna Loehman*, Nir Becker", Eythan Weg “*, Margaret Hendrickx * \\ "Purdue University, Lafayette, IN, USA;"* Haifa University and Tel-Hai Rodman College, \\ Israel,"”Indiana University, Bloomington, IN, USA
}

We propose a regional cooperative water management system that combines aspects of a nonprofit regional utility and a representative governing body. The conceptual basis is temporal economic efficiency. To help the utility make acceptable management decisions, a representative body of water users would express willingness to pay for water security relative to values of current water use and other consumption. Established limits on groundwater withdrawal would ensure sustainability and be sufficient to determine water prices through the balance of supply and demand. Security in terms of groundwater storage would be achieved through investment in recovery/recycling. Simulation modelling indicates that water prices over time could fall as investment and storage increase. While a traditional market could improve spatial allocation, it would not necessarily address sustainability or provide for investment.

KEYWORDS: aquifer, management, pricing, sustainability, utility, water,

\section{INTRODUCTION}

Water scarcity and quality problems are a world-wide phenomenon (Clarke, 1993). Onefourth of the world's population is at risk of water stress or scarcity, according to Swedish hydrologist Falkenmark. Current water use in Israel and other parts of the Middle East are beyond the "water barrier", with less than $500 \mathrm{~cm}$ of water per person (Clarke, 1993, p.67). In Israel, investment in new irrigation technology has reduced water use by more than a third while doubling productivity (Committee on Sustainable Water Supplies for the Middle East, 1999). Such technology can be transferred to other water-short areas given adequate financial resources and incentives.

Particularly in the Middle East, cooperative management and investment could improve the well-being of all parties. Cooperative agreements about water already exist: e.g. the Annex to the Israel-Jordan Peace Treaty for Water-related matters and the U.S.-Israel-Palestinian Trilateral agreement to promote cooperative efforts to increase the availability and more efficient use of water resources.

We propose a social institution to implement cooperation regarding intertemporal water management based on economic principles. A nonprofit cooperative organization, including aspects of a regional utility and a joint commission, can carry out intertemporal water management and investment in water recycling/ recovery. In this context, pricing rules can promote efficient use of water subject to equity and sustainability constraints. 
A hydro-geologic system - such as the Mountain Aquifer which straddles Israeli and Palestinian lands - can be viewed as a commons that provides a time-stream of benefits over a geographic area. As discussed by Ostrom (1990), successful commons arrangements require appropriate boundaries and rules. Population increases and other stresses can make commons arrangements difficult (Bromley, 1992). Naturally occurring institutions are not always adequate to promote cooperation. For example, oil companies could gain by joint management of the oil fields but often have not done so (Libecap, 1989). The approach of explicit institutional design for resource dilemmas (Loehman and Kilgour, 1998; Seabright, 1993) can take into account complexity and information problems to achieve "commons without tragedy" (Andelson, 1991).

Water management is increasingly organized along watershed lines (Kenney, 1997). For example in the U.S., water districts provide water for local irrigation and domestic uses. When water was less scarce, demand for water was taken as given, and supplies were planned to meet demand (supply side management). With increasing scarcity, demand management aims at balancing demand with a limited supply.

Commonly, demand management refers to education to increase adoption of waterefficient practices, and pricing has not been an emphasis. However, economists prefer price incentives to promote efficient use and adoption of improved technologies (Rogers, 1993). While pricing is usually associated with markets and privatization, the regional utility approach that we propose also results in prices while addressing equity, sustainability, and investment concerns.

\section{BACKGROUND: WEST BANK AND MOUNTAIN AQUIFER}

The Mountain Aquifer $\sim$ for the most part under the West Bank $\sim$ is the source of about $30 \%$ of the fresh water supply in Israel and is the most important source of fresh water for Palestinians in the West Bank (Isaac, 1998). The annual amount of rain averages $600 \mathrm{~mm}$ per ha. The aquifer can be divided into three major units: the Western basin with a $350 \mathrm{mcm}$ safe yield, the Northeastern basin with a safe yield of $140 \mathrm{mcm}$, and the Eastern basin with an annual 125 $\mathrm{mcm}$ safe yield. Out of the total annual average recharge of $615 \mathrm{mcm}$ per year, Israel uses about $490 \mathrm{mcm}$ while the Palestinians use about $125 \mathrm{mcm}$ per year (Isaac, 1998). Comparing the amount of water used for irrigation, use is $300 \mathrm{~cm}$ per capita per year in Israel versus $70 \mathrm{~cm}$ in the West Bank. The population of the West Bank is roughly a million people.

Wastewater is a major concern. With treatment, it could serve as an additional source of water, but otherwise is hazardous for the aquifer and for the well-being of users. Current wastewater volume is about $45 \mathrm{mcm}$ per year.

Previous studies have investigated the implications of potential water market trading and valuation. From spatial optimization for the West Bank, an additional $100 \mathrm{mcm}$ should be diverted to the Palestinians; modeling implies an equilibrium water price of about $40 \mathrm{cents} / \mathrm{cm}$ with a shadow price of about 80 cents/cm (Becker and Zeitouni, 1998). Similarly, Fisher (1995) 
found that: "the value of the water in dispute among the parties is not great. Using a liberal estimate, it is currently a maximum of $\$ 110$ million per year and will rise to a maximum of less than $\$ 500$ million per year by 2020 . Such values are small compared with the economies involved....compared with the cost of military equipment." (p. 386)

The market approach for Middle East problems is of continuing interest (Fisher, 1995; Becker et al., 1996). Cooperative management has also received attention (Eckstein et al., 1994; Haddad and Feitelson, 1994; Committee on Sustainable Water Supplies for the Middle East, 1999). Implementation of these concepts is the next step (Yaron, 1991).

\section{ALTERNATIVE WATER MANAGEMENT ORGANIZATIONS}

Several types of institutions relevant for managing water include centralized planning, public utility, market-like institutions, and voluntary associations. Desirable characteristics relevant to choosing institutions (Hurwicz, 1994) include minimizing enforcement costs, information costs, and efficiency losses. Achieving fairness is another important characteristic of viable social institutions (Young, 1994).

A government agency carrying out centralized planning has advantages of being able to maintain information over time about the resource base, to obtain funds through taxes to carry out development projects, and to punish those who violate rules. It has disadvantages of not having incentives for cost minimization and not receiving appropriate signals about preferences. Therefore, a government agency may not be successful in achieving desired goals. At the opposite extreme, successful voluntary organizations have popular support, but they lack the resources to carry out programs and collect needed information, and have no authority to obtain compliance with social goals.

In "pure private good" cases, market institutions can achieve efficient outcomes consistent with preferences through decentralized information and decisions: each market participant's separate decisions create the ultimate group solution. A market may also be considered to be fair for those with resources to participate in the market, since each market participant pays the same price; i.e. the market is "anonymous" with respect to identity of individual buyers.

Markets are known to "fail" to achieve efficiency in nonstandard situations such as public investment and externalities. Private investment requires an economic return over a time horizon that may be shorter than the social time preference rate (Kula, 1997). Thus, the market may not result in adequate investment in water quality. Furthermore, functioning markets require the determination of property rights, or initial allocations from which trade can occur. The issue of rights has been a major bone of contention for water problems.

The public utility is an intermediate type of institution between a market and centralized planning. A utility maintains a production and distribution system for a local service area, makes 
plans for future conditions, and finances investment through local user revenues, usually with pricing. A public water utility does not own the water it manages. There is a contractual arrangement with citizens for whom water is managed, and dissatisfaction by citizens with management can result in the replacement of one management team with another! Prices for utilities are frequently regulated by a public agency that may also impose service quality and fairness constraints. Thus, a utility operates in a mixed public-private setting. Below we make the argument that the public utility is an appropriate type of organization to achieve temporal efficiency in water management.

\section{ECONOMICS OF TEMPORAL EFFICIENCY}

\section{Social Choices}

Water management in an aquifer is a problem of distribution over time as well as space. The spatial problem is, for each time period, how to allocate water geographically over current users. A market would primarily address spatial distribution. Here we focus on the temporal problem. By temporal efficiency, we mean that there is no reallocation of water withdrawal and investment that would yield a higher level of welfare for the region in every time period.

Any regional management agency would need to address several management choices. The level of storage in the aquifer over time is one type of choice. Storage in an aquifer acts like insurance against future low rainfall risk, since rainfall can be highly variable over time: the greater the level of the aquifer, the greater the insurance, or more years of drought that could be withstood. Storage issues for groundwater relative to rainfall are similar to questions of reserve releases for an oil reserve program (Horwich, 1984); in both cases, price stabilization is relevant. The sustainability of the local aquifer is an additional issue for ground water.

Another type of choice is investment in recycling/recovery to mitigate effects of low rainfall. Investment requires expenditure of resources, thus reducing current consumption in order to obtain future gains. Providing a guaranteed level for water to households is another potential social policy related to water security: regardless of rainfall conditions, the guaranteed amount of water would be available. A higher guarantee would typically require more investment and higher water prices under conditions of scarcity.

\section{A Simulation Model of Optimal Withdrawal and Investment}

We briefly describe a simulation model for optimal storage, investment, and pricing decisions. First are the constraints. There is a sustainability constraint that the storage level should not fall below the "safe" level. The guarantee or security level for water to households is also specified as a constraint to be met; it is $200 \mathrm{mcm}$ initially, with a growth rate of $2 \%$. Household population also grows at $2 \%$. (Parameters were chosen to be similar to characteristics of the West Bank; parameterization and specifics of the model are available from the authors.) 
Other constraints concern water balance. Regarding the dynamics of the aquifer: the change in storage equals net recharge minus withdrawal. Regarding demand-supply balance: supply (recovered water plus surface sources plus groundwater withdrawal) must equal total demand for household and production uses.

Rainfall is variable from year to year. To develop a relationship between prices and rainfall, we specified rainfall as a trigonometric (deterministic) function. The rainfall pattern was cyclical with a low of $77 \mathrm{~mm}$ and a high of about $900 \mathrm{~mm}$. (Future work can use an explicit risk model.)

Given rainfall variability, the group of water users acts jointly to maximize the group's total welfare over time, here represented by twenty periods. Total household welfare derives from direct water use for food and other uses, consumption of nonfood goods, labor supplied, and water security. (Preferences are not differentiated by type of household in this model.) Greater security for future water use with possible droughts is obtained with more groundwater storage. The nature of preference is assumed to be the same in each period, and we do not use a discount rate for future consumption.

Investment can increase recovered water available for domestic and production purposes. The cost of investment increases with the volume of water recovery and the percent of use recovery; higher percents imply higher per unit costs. The cost for pumping groundwater varies with the volume withdrawn. The storage level also affects cost; a lower storage level relative to capacity means a higher pumping cost. Paying for pumping and investment costs reduces the consumption available to households.

Maximizing the group welfare for a stream of returns over time subject to the constraints and rainfall variation, the following results are obtained (see Figure 1). In the initial year, the storage condition is very close to the overdraft limit, so there is virtually no withdrawal. The optimal storage level (after withdrawal) gradually increases, with some minor fluctuation reflecting the rainfall pattern; at the beginning of the period it is $43 \%$ of capacity and $58 \%$ by the end of the period. The storage increase is possible because of recycling/ recovery. Initially recovery percent is high, at about $40 \%$ of total volume because of overdraft and drought, and then decreases to about $28 \%$ of total volume. The recovery volume more than doubles over the entire period. The percent of gross product devoted to investment in recycling/ recovery decreases gradually; it stabilizes in the range of $15 \%$, after an initial higher value. Total household total use gradually increases from $288 \mathrm{mcm}$ to $910 \mathrm{mcm}$ as the storage level and recycling increase. Similarly, water for nonfood production rises gradually through the period. The household use shows more cyclical variation with rainfall than nonfood production.

\section{Pricing}

Economic theory of dynamic optimization provides guidelines for setting price. The shadow price of withdrawal refers to its effect on reducing future water use associated with the 
dynamic water balance equation. The economic price of water is associated with achieving demand-supply balance: it is the sum of marginal pumping cost and the shadow price.

Furthermore, price should also equal the marginal investment cost for additional recovery. And, from supply-demand balance, the same price should be placed on surface, ground, and recovered water (here, ignoring quality differences).

From the optimization, shadow prices, and cost functions for the model, the implied price of water is $\$ 0.81 \mathrm{per} \mathrm{cm}$ at the beginning of the period, and because of the supply increase, price decreases to $\$ 0.55$ per $\mathrm{cm}$ at the end of the period. (There is a spike in the next to last year reflecting the previous year's extreme drought.) Price is related to rainfall, peaking when the rainfall is very low and low when rain is high. Interestingly, the variation in all variables, including price, is less than the variation in rainfall. Thus, the management of the system stabilizes rainfall effects. Although fairly stable at the end of the period, the system does not go to a steady state because it responds to extremes in rainfall conditions.

\section{A REGIONAL UTILITY IS A TEMPORALLY EFFICIENT MANAGEMENT ORGANIZATION}

A nonprofit water utility with correct pricing rules can be shown to satisfy temporal efficiency (derivation available from authors). The utility would make withdrawal, investment, and pricing decisions over time subject to hydro-geologic conditions, funding investment from user revenues. It would also maintain the knowledge base about the water resource system.

Domestic users and producers would operate in a "spot" market, and would not have to keep track of the aquifer storage situation directly. Household and other productive users would choose water use period by period, given price for water.

This system does not need property rights to determine prices, simply the interaction of

supply and demand, once a withdrawal limit is set. Figure 2 explains why the price of water can actually be reduced with more recycling because of more effective water availability. The household impact of water pricing can be mitigated by using block rate pricing such that price increases with use, starting from a flat rate for the guaranteed level and reaching the level of marginal cost for the system.

IMPLEMENTATION AND GROUP PROCESS: FOSTERING COOPERATION

\section{Information Needs and Group Process}

Application of optimization modelling as described above is limited by information problems. First, the regional water utility must obtain preference information to set prices and determine investments. Assuming each generation would have the same preference relation, the utility could obtain preference information in the form of willingness to pay for current water use and for future water security from representative current users. 
Second, there is the problem that rainfall pattern is not known ex ante. Our simulations indicate that price and investment should depend on rainfall. Although the system has a tendency toward stability, variables respond to extreme conditions. Some researchers have suggested basing prices on expected values for rainfall in an optimization framework (Conrad and Clarke, 1987), but then there could be no price variation to counteract cyclical rainfall conditions!

A group process could determine a target storage level according to security preferences, and also the adjustment path (how fast to approach the target given the initial conditions). This information can then be translated by the utility into water use limits and then to price according to efficiency rules. To assist the group decision-making process, simulation can indicate potential price effects of guarantee levels and rainfall conditions.

\section{Acceptability of Regional Management}

The organization suggested by our economic model involves a regional water management utility interacting with representative water users for the following purposes.

(a) water users would need to accept the proposed organizational framework;

(b) representative users would need to provide preference information to assist in determining the storage target, adjustment path, and guarantee level;

(c) once prices are determined, users should accept the outcome.

While economics is useful to describe efficiency, psychology and strategic management are more relevant for indicating conditions for success of a group.

Game theory can explain why current owners of water rights might be willing to relinquish security provided by water rights to join such an organization. If owners are limited to their own resources, without access to investment and reallocation through potential trade in water, their effective supply is limited to what is locally available. Analogous to a homeowner buying insurance against natural risks, one can insure against water distribution risk by pooling water sources and investment funds through cooperation. Game theory shows that such a situation can have stable cooperative equilibrium. Furthermore (Guth, Schmittberger, and Schwarze, 1982), one party will not dictate an extreme (unjust) splitting of a shared resource if another party can make a choice such that all lose.

\section{Achieving Successful Group Interaction through Organizational Rules}

Interaction among different interest groups can be difficult when there are value differences among group members. Transactions costs to reach agreement can be large, and there may be minorities who fear that dominating factions may force an outcome.

According to mediation theory, the perception of a common ground in framing a group 
process can be important for its success. A common ground exists whenever the participants in a decision-making process experience shared commitment to cope with problems or issues (Gray, 1989), such as sustainable water management. If group members place a value on a successful group outcome, they may be willing to relax pure self interest, and hence a group outcome is possible in spite of individual differences. Social psychologists have shown that when participants with different values can openly discuss their diverse viewpoints in the decision process, they can become more committed to any decision eventually reached (Moscovici, 1994).

Perceived justice and equity are considered among the most important criteria for success of a group process (Mikula, 1980). Two characterizations are: rule fairness (or procedural justice) and outcome fairness (or distributive justice); Zajac, 1995. According to outcome fairness, a decision process is considered just or fair when the distribution which results from the process is considered fair. Rule fairness is experienced when the procedural systems that regulate the distribution of rewards and resources are interpreted as fair. Participation in a decision-making process increases perceptions of procedural fairness and acceptance of the decision regardless of the nature of the outcome (Vroan and Yettar, 1973).

Since any procedure originally perceived as fair can lead to an outcome distribution that seems unfair, an organization should have procedures to adjust for any perceived problems. Procedural components important for successful group processes have been identified (Leventhal, Karuza and Fry, 1980: pp. 170-71):

(1) selection procedures for agents who will make decisions, collect information or safeguard the allocative process;

(2) procedures for setting and clearly communicating the ground rules;

(3) a structure for the actual decision process by which resources are distributed;

(4) safeguard procedures which ensure that agents who administer the allocative process are performing their duties properly

(5) grievance or appeal procedures, which may be either formal or informal

(6) a change mechanism (voting or negotiation procedures) for allocative procedures.

\section{CONCLUSIONS}

This paper discusses how organization of a regional water utility could be based on achieving temporal economic efficiency with a sustainability constraint. The non-profit utility would establish limits on water use, determine water prices to set supply equal demand, and make investments from system revenues. A representative body of water users would help the utility determine appropriate limits and guarantees based on group values. Not only economics but also the organizational structure of such a group will be important for its success. Markets would not provide the requisite temporal and social management elements. 
REFERENCES

Allen, J.A. (1996). Water, Peace, and the Middle East Tauris Academic Studies, St. Martin's Press.

Andelson, R.V. (1991). Commons without Tragedy. London: Shepheard-Walwyn.

Beaumont, P. (1994). The Myth of Water Wars and the Future of Irrigated Agriculture in the Middle East. International Journal of Water Resources Development 10: 9-22.

Becker N. and Zeitouni, N. (1996). Reallocating Water Resources in the Middle East Through Market Mechanisms. International Journal of Water Resources Development 12: 17-32.

Benvenisty, E. and Gvirtzman, H. (1993). Harnessing International Law to Determine IsraeliPalestinian Water Rights: The Mountain Aquifer. Natural Resources Journal 33: 543-567.

Berck, P. and Lipow, J. (1994). Real and Ideal Water Rights: The Prospects for Water Rights Reform in Israel, Gaza and the West Bank. Resources and Energy Economics 16: 287-302.

Bromley, D. (1992). The Commons, Common Property, and Environmental Policy. Environmental and Resource Economics 2: 1-17.

Committee on Sustainable Water Supplies for the Middle East (1999). Water for the Future, The West Bank and Gaza Strip, Israel and Jordan. Washington, D.C.: National Academy Press.

Conrad, Jon M. and Clark, Colin W. (1987). Natural Resource Economics. Notes and Problems. New York, NY : Cambridge University Press.

Dinar, A. and Wolf, A. (1994). International Markets for Water and the Potential for Regional Cooperation: Economic and Political Perspectives in the Western Middle East. Economic Development and Cultural Change 43: 43-66.

Eckstein, Z., Zackai, D. and Nachtom, Y. (1993). The Division of Water Sources Between Israel, the West Bank and Gaza: An Economic Analysis. Manuscript, the Armand Hammer Institute for Peace, Tel-Aviv.

Elmusa, S. S. (1995). Dividing Common Water Resources According to International Water Law: The Case of the Palestinian-Israeli Waters. Natural Resource Journal 35: 223-241.

Fisher, F.M. (1995). The Economics of Water Dispute Resolution, Project Evaluation and Management: An Application to the Middle East. International Journal of Water Resources 11:377-391. 
Gray, B. (1989). Collaborating: Finding Common Ground. San Francisco, CA: Jossey-Bass Publishers

Guth, Werner, R. Schmittberger, and Schwarze, B. (1982). An Experimental Analysis Of Ultimatum Games, Journal of Economic Behavior and Organization 3: 367-388.

Haddad, M. and Feitelson, E. (1995). Joint Management of Shared Aquifers. Jerusalem, Israel: The Harry S. Truman Research Institute.

Horwich, George and Weimer, David Leo (1984). Oil Price Shocks, Market Response, and Contingency Planning. Washington, DC: American Enterprise Institute for Public Policy Research.

Hurwicz, L. (1994). Economic Design, Adjustment Processes, Mechanisms, and Institutions. Economic Design 1: 1-14.

Isaac, J. (1998). A Palestinian Perspective on the Water Crises. Palestine-Israel Journal of Politics, Economics and Culture. Vol. 5(1): 54-58.

Kenney, Douglas S. (1997). Resource Management of the Watershed Level: An Assessment of the Changing Federal Role in the Emerging Era of Community-Based Watershed Management. Boulder, CO: University of Colorado School of Law

Kula, E. (1997). Time Discounting and Future Generations. Westpoint, Conn: Greenwood, Quorum Books.

Larker, Robin (1993). Water, The International Crisis. London, UK: Earthscan Publications LTD.

Leventhal, Gerald S., Karuza, Jurgis Jr. and Fry, William Rick (1980). Beyond Fairness: A Theory of Allocation preferences. In: Justice and Social Interaction. Experimental and Theoretical Contributions from Psychological Research. New York, NY: Springer-Verlag: $167-218$

Libecap, Gary D. (1989). Contracting for Resources. Cambridge, MA: Cambridge University Press.

Loehman, E. and Kilgour, M. (1998). Design of Institutions for Environmental and Resource Management. Elgar Press.

Mikula, Gerold (1980). Justice and Social Interaction. Experimental and Theoretical Contributions from Psychological Research. New York, NY : Springer-Verlag. 
Moore, J.W. (1994). Defining National Property Rights to Common Property Resource: The Case of the West Bank Aquifers. Resources and Energy Economics. Vol. 16(4): 373-391.

Moore, J.W. (1994). An Israeli-Palestinian Water-Sharing. In Water and Peace in the Middle East. Isaac, J. and Shuval, Hillel (Eds). Elsevier Science.

Moscovici, Serge and Doise, Willem (1994). Conflict and Consensus. A General Theory of Collective Decisions. Thousand Oaks, CA: Sage Publications.

Ostrom, E. (1990). Governing the Commons: the Evolution of Institutions for Collective Action. New York: Cambridge University Press.

Roger, Peter (1993). America's Water. Federal Roles and Responsibilities. Cambridge, MA : MIT Press.

Seabright, Paul (1993). Managing Local Commons: Theoretical Issues in Incentive Design. Journal of Economic Perspectives 7: 113-34.

Shuval, Hillel (1994). Proposed Israeli-Palestinian Water-sharing, in Water and Peace in the Middle East. Isaac, J. and Shuval, Hillel (Eds). Elsevier Science.

Walster, E., Berscheid, E. and Walster, G.W. (1973). New Directions in Equity Research. Journal of Personality and Social Psychology, 25, 151-176.

Walster, E., Walster, G.W. and Berscheid, E. (1978). Equity: Theory and Research. Boston, M A: Allyn and Bacon.

Yaron, D. (1994). An Approach to the Problem of Water Allocation to Israel and the Palestinian Entity. Resources and Energy Economics 16: 271-287.

Yaron, D. (1991). Prices and Quotas in Water Policy (in Hebrew), Agr. Econ. Quarterly 150:440-64.

Young, H. P. (1994). Equity in Theory and Practice. Princeton, NJ : Princeton University Press.

Zajac, D (1995). Political Economy of Fairness, Cambridge, M A : MIT Press.

Zeitouni, N., N. Becker and M. Shechter (1994). Models of Water Market Mechanisms and an Illustrative Application to the Middle East. Resources and Energy Economics 16: 303-320. 


\section{Appendix: Theoretical Development of Efficient Organization and Pricing Rules}

\section{Temporal Efficiency Problem}

The problem is to choose the time path of withdrawal ("draw") and "investment"; these are the control variables. The choice should maximize aggregate group welfare u(.) over time, as indicated by the integral below. The form $u($.$) is assumed to be the same each time period. The$ period of time is $T$ years. Arguments of the utility function are:

labor: labor supplied by households (a negative factor for utility);

consume: net consumption by households;

whouse: water used by households;

security: storage level above overdraft limit $(\operatorname{security}(t)=$ gwstorage $(t)-$ safe $)$;

r: population growth rate.

$$
\underset{\text { draw, invest. }}{\operatorname{Max}} \int_{0}^{T} u t i l\left(\operatorname{labor}(t) \times e^{r t}, \text { consume }(t), \text { whouse }(t), \operatorname{security}(t)\right) d t
$$

Subject to constraints (shadow prices in parentheses):

Groundwater storage change $(\lambda)$ :

$$
\Delta \text { gwstorage }(\mathrm{t})=\mathrm{s} 1 * \operatorname{rain}(\mathrm{t}) * \operatorname{area}-\operatorname{draw}(\mathrm{t})-\mathrm{s} 3 \text { gwstorage }(\mathrm{t}) ;
$$

Supply equals demand $\left(\mathrm{p}_{\mathrm{w}}\right)$ :

$$
\text { whouse }(t)+\operatorname{wprod}(t)-\delta \operatorname{rain}(t) \leq \operatorname{surface}(t)+\operatorname{recover}(t)+\operatorname{draw}(t)
$$

Consumption equals value of production minus costs $(\tau)$ :

$$
\text { consume }(t) \leq \text { output }(t) \text {-investment }(t) \text {-pumpcost }(t) ;
$$

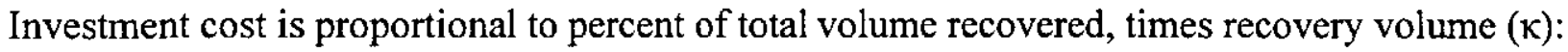

$$
\text { investment }(\mathrm{t}) \leq \mathrm{c} 1 * \text { percent }(\mathrm{t})^{*} \text { recover }(\mathrm{t}) \text {; }
$$

Guaranteed level of water for households regardless of rainfall $(\varepsilon)$ :

$$
\text { whouse }(t) \geq \text { guarantee; }
$$


Production function for output $(\mu)$ :

$$
\operatorname{output}(\mathrm{t}) \leq \mathrm{f}(\operatorname{labor}(\mathrm{t}), \operatorname{wprod}(\mathrm{t}))
$$

Additional specifications are:

$$
\begin{aligned}
& \text { util }(\mathrm{t})=\left((1+\text { labor }(\mathrm{t}))^{* *} \mathrm{a} 1\right)^{*}\left((1+\text { consume }(\mathrm{t}))^{* *} \mathrm{a} 2\right) \\
& *\left((1+\text { whouse }(\mathrm{t}))^{* *} \mathrm{a} 3\right)^{*}\left((1+\operatorname{security}(\mathrm{t}))^{* *} \mathrm{a} 4\right)^{*} \exp \left(\mathrm{r}^{*} \mathrm{t}\right) \text {; } \\
& \operatorname{output}(\mathrm{t})=\mathrm{b} 1 *\left((1+\operatorname{labor}(\mathrm{t}))^{* *} \mathrm{~b} 2\right)^{*}\left((1+\mathrm{wprod}(\mathrm{t}))^{* *} \mathrm{~b} 3\right) \\
& \text { labor }(\mathrm{t}) \leq 8^{*} \exp \left(\mathrm{r}^{*} \mathrm{t}\right) \\
& \operatorname{recover}(t) \leq \operatorname{percent}(t)^{*}(\text { whouse }(t)+\operatorname{wprod}(t)) ; \\
& \operatorname{pumpcost}(t) \geq c 2 * \operatorname{draw}(t) /(1+\operatorname{percap}(t)) ; \\
& \text { percap }(t)=\text { gwstorage/storagebd; } \\
& \text { gwstorage }(\mathrm{t}) \leq \text { storagebd; } \\
& \text { surface }(\mathrm{t})=\mathrm{s} 2 * \text { rain } * \text { area. }
\end{aligned}
$$

Direct rainfall used by households and producers (e.g. for crops and gardens) is not included in "surface". "wprod" denotes water for production; "storagebd" denotes aquifer capacity; "pumpcost" denotes pump cost for "draw" as related to pressure in the aquifer.

First order necessary conditions for optimization over each choice variable are as follows, given in terms of the shadow prices (time superscript omitted). Interpretations are indicated in parentheses. Parameters are set so that $\tau$ is approximately equal to one:

labor (marginal dis-utility of labor equals its marginal value product):

$$
\text { util }_{1}=-\mu \text { output; }
$$

wprod (price of water equals its marginal value product):

$$
\mathrm{p}_{\mathrm{w}}=\mu \text { output } \mathrm{w}_{\mathrm{w}}
$$

consumption (marginal utility of consumption is the numeraire, approximately $\$ 1$ ):

$$
\operatorname{util}_{\mathrm{c}}=\tau \text {; }
$$


output (equalization of shadow prices):

$$
\mu=\tau
$$

whouse (marginal utility of water equals its price, for a nonbinding guarantee constraint):

$$
\text { util }_{w}=p_{w} \text { for } \varepsilon=0
$$

investment (equalization of shadow prices):

$$
\tau=\kappa ;
$$

recover (water price equals marginal investment cost of recovery, related to percent):

$$
\mathrm{p}_{\mathrm{w}}=\kappa \mathrm{c}_{1} \text { percent; }
$$

draw (water price equals the sum of shadow price of storage and marginal pumping cost):

$$
p_{w}=\lambda+\text { pumpcost }_{d} \tau
$$

storage (optimization condition):

$$
\Delta \text { lamda(t) }=-u t i l_{s}+\tau \text { pumpcost }_{s}-s 3 \text { lamda(t). }
$$

The last three conditions are particularly interesting. The multiplier associated with the condition that supply equals demand has the interpretation as price for water. The condition for "draw" then has the interpretation that price for water should be composed of two parts: the shadow price reflecting the long term value of reducing the draw in this period, and the short term marginal cost of pumping. The "storage" condition implies that when the storage increases, the shadow price will decrease. The condition on "recover" indicates that water price will also be equal to marginal investment cost for recovery, depending on the percent recovered.

If there is a steady state, draw from groundwater equals the recharge, but this could occur at any storage level. Since rainfall is varying, this means that recovery of water from current use would have to offset rainfall effects. When rainfall is less, recovery should increase and with it, investment in recovery. It may not be possible to offset diminished rainfall completely, and there may be some lag, so that a steady state may not be possible. 


\section{Efficient Organization and Pricing}

An organizational structure that could satisfy the temporal optimization problem would have consumers and producers in spot market and a public utility making temporal decisions.

Households choose water purchased, after direct rain utilization is subtracted from needs, given the price of water. Households also pay a fee to the managing utility for maintaining a secure level of water in the aquifer. Households receive income for labor that is used to pay for consumption and water. The problem is solved myopically each time period:

$$
\begin{gathered}
\operatorname{Max}_{\text {whouse(t) }} \text { util }(\text { labor }(t) \text {, consume }(t) \text {, whouse }(t) \text {, security }(t)) \\
\text { s.t. } \quad p_{s} \text { security }(t)+p_{w}\left(\text { whouse }(t)-\delta_{h} \text { rain }(t)\right)+\text { consume }(t) \leq \text { wagexlabor }(t)
\end{gathered}
$$

Producers choose inputs of labor and water each time period according to the production relationship and prices. The price for water is applied to water needs beyond direct rain utilization. Decisions are represented by:

$$
\begin{aligned}
& \underset{\operatorname{Max}(t), \operatorname{wprod}(t)}{\operatorname{output}(t)}-\text { wage } \times \operatorname{labor}(t)-\mathrm{p}_{w}\left(\operatorname{wprod}(t)-\delta_{\mathrm{p}} \operatorname{rain}(t)\right) \\
& \text { s.t. } \operatorname{output}(t)=f(\operatorname{labor}(t), \operatorname{wprod}(t))
\end{aligned}
$$

The public utility is responsible for temporal allocation decisions. The utility receives revenue for maintaining the storage and for water purchased and makes investments from the revenues. Surface use (excluding direct rain utilization by households and producers), groundwater withdrawal, and recovery should all receive the same price. The form of the utility's problem is:

$$
\underset{\text { draw,invest. }}{\operatorname{Max}} \int_{0}^{T}\left[p_{S} \operatorname{security}(t)+p_{w}(\text { surface }(t)+\operatorname{draw}(t)+\operatorname{recover}(t))-\operatorname{pumpcost}(t)-\text { investment }(t)\right] d t
$$

subject to constraints:

$$
\begin{gathered}
\Delta \text { gwstorage }=s 1 * \operatorname{rain}(t) * \text { area }-\operatorname{draw}(t)-s 3 * \text { gwstorage; } \\
\text { investment }(t) \leq \mathrm{cl} 1^{*} \operatorname{percent}(t) * \operatorname{recover}(t) \\
\operatorname{pumpcost}(t) \geq c 2 * \operatorname{draw}(t) /(1+\operatorname{pumpprs}(t))
\end{gathered}
$$

Additional equilibrium conditions and requirements that must hold in each time period are: 
supply equals demand at price $\mathrm{p}_{\mathrm{w}}$ :

$$
\text { whouse }(t)+\operatorname{wprod}(t)-\delta \operatorname{rain}(t) \leq \operatorname{surface}(t)+\operatorname{recover}(t)+\operatorname{draw}(t) ;
$$

zero profit for the public utility:

$$
p_{S}(\operatorname{security}(t))+p_{w}(\operatorname{surface}(t)+\operatorname{draw}(t)+\operatorname{recover}(t))=\operatorname{pumpcost}(t)+\operatorname{investment}(t)
$$

the guarantee level for household water needs:

$$
\text { whouse }(t) \geq \text { guarantee. }
$$

The above specifications define the functional relationships.

By comparing first order conditions, we see that the Temporal Equilibrium Problem (II) satisfies the efficiency conditions for the Temporal Efficiency Problem (I). Feasibility of net consumption is implied by the zero profit condition. Thus, it is possible to find a temporally efficient solution through decentralized decisions for consumers and producers with the right prices. 